As stated in its report for 1940, the Committee is in general agreement with the paragraphs on forest insect protection in the preliminary statement on Forest Policy prepared by the Ottawa Valley section, and with the manner of its placing in the whole body of the report (under Forest Research. 4. Protection. b. Insects). However, it would like to recommend that certain changes in wording should be made in the three places enumerated in the full report of this Committee.

At the request of the secretary of the Society, the whole question of salvage of insect-damaged timber was examined in greater detail. It was considered that salvage would be economically feasible in a small proportion of the huge area damaged, particularly in cases of mills dependent on small or depleted limits. It was felt that the appropriate inducement for salvage was a reduction in crown dues on stumpage. In this connection it may be noted that New Brunswick has a provision for 50 per cent reduction, Alberta up to 50 per cent reduction, and Quebec up to 20 per cent reduction on insect-damaged timber. Manitoba and British Columbia have statutory provision for a reduction of up to 50 per cent on fire-killed timber. No statutory provision is known to exist for any reduction of stumpage for insect damage in Ontario.

It was considered that the government concerned would feel justified in offering stumpage reduction only when the alternative to reduced dues was no dues at all, i.e., the result of its non-granting would result in a net loss in the volume cut.

In the case of Ontario, it is recommended that a resolution be made by the Society empowering its Secretary-Treasurer to make a special study of the conditions at present existing re salvage of insect-damaged timber in that province.

In the case of New Brunswick, it is recommended that a resolution be made by the Society requesting its Maritime Section to make a special study of the manner in which the existing provisions for stumpage reduction in that province actually operated in practice. It was felt by the committee that the two pertinent articles, namely 23 and 24 , in the Timber Regulations did not allow a satisfactory settlement of the stumpage question.

In the case of Quebec, it is recommended that a resolution be made by the Society to approach the Quebec Society of Forest Engineers with a sug. gestion that they make a study of the actual operation of the stumpage reduction provisions in that province. The committee understands that al. though the latest Order-in-Council covering stumpage rates includes a general paragraph which seems to allow reasonable provision for stumpage reduction, yet cases are extremely rare in which the Minister grants such reduction, under the meaning of this Order-in-Council.

A resolution embodying the points discussed above is hereby submitted for the consideration of the Society at its annual meeting.
E. E. SHAW, Chairman.
A. W. A. BROWN, Secretary.

\title{
FARM WOODLOTS
}

Previous reports have dealt with the problem in various ways and re ported progress. This year we are discussing forest policy. It may be in 
order then to consider forest policy briefly here from the farm woodlot standpoint.

Like other forest owners, farmers should put the principles of forestry into practice. Like other forest owners, each farmer operates his woodlot under conditions which govern his policy. Being human, the farmer considers costs, losses and returns. He does not like to work for nothing and he has not much spare time. Conditions vary almost as much between different localities as they do between farm woodlots and larger forests. It is difficult to state general policies which should apply to farm woodlots beyond the fundamentals of protection, reproduction, growth and use which apply to all forests.

We might assume an average set of conditions and design a policy to fit them. But when conditions vary from the South Ontario woodlot of ten acres of maple, ash and walnut to one hundred acres or more of spruce and balsam fir in New Brunswick and from the colonist whose chief income is from his woodlot to the Prince Edward Island farmer who prefers to buy coal rather than cut his own firewood, then an average does not mean very much.

Farm woodlot policy is a personal problem for each farmer. He must decide what and when to cut, where and how to market. His knowledge of trees and how they grow and their reaction to cutting methods is limited. By personality he is usually an exploiter or a conservationist. Either extreme is bad for the community.

It is to the interest of a community that a part of the land area remain forested and that this forest land be kept productive. The first problem is one of education. Regulation of a non-co-operating minority may come later. Provincial Governments are responsible to the people for necessary action.

Government action or policy is usually in response to the voice of the people, but may be guided by technical advisers who have the Government's confidence. The policy of the profession should, therefore, attempt to (1) encourage the people to demand advice and education in forestry and (2) be prepared to advise governments of the best approach to the problem.

The following is an outline of conditions and progress in the various provinces of Eastern Canada.

\section{Prince Edward Island}

About one-third of the area of Prince Edward Island is forested. This forested area is all privately owned and most of it is in woodlots on occupied farms. The forest is composed of the ordinary associations found in its region. Most of the land is suitable for cultivation and there is danger of too much clearing if the farming becomes sufficiently attractive. Hedges along the roads are being removed to allow the wind to sweep the roads to clear snow in the winter. These hedges are too close to the roads to act satisfactorily as snow fences.

In 1940 the Provincial Government engaged the services of a forester for extension work. A contact had been established by the Dominion Forest Service which encouraged this step. The initiative for the service came from the Government rather than the people and when the necessity for 
retrenchment because of increasing war measures was felt the extension forestry service was abolished.

The forests of the Island, if properly managed and used, would supply most of the needs of the population for wood and lumber. Many individual owners lack knowledge of the forest values and methods of cutting and handling. As a result forests are standing idle while lumber, firewood and coal are brought from the mainland.

The situation clearly demands education in forest values and forestry methods to arouse the interest and support of the people.

\section{Nova Scotia}

Farm woodlots in Nova Scotia include more than one-third of the productive forest area of the province and are the most accessible and productive of the forests. Value of products amounts to about 12 per cent of the gross value of farm produce, varying from 8 per cent in the highly specialized fruit growing district of the Annapolis valley to 20 per cent in some other communities. In cash this amounts to more than $\$ 4,000,000$ per year. The maintenance of the productive capacity of the farm woodlots is therefore extremely important to the farming communities in Nova Scotia.

Several years ago the Province of Nova Scotia established a forestry extension service in connection with its Department of Agriculture. The approach to the problem was the education of woodlot owners to a better understanding of the importance of farm woodlots and their products in the economy of the Province. The program includes:

(1) Organization of the primary producers of every farm community to promote centralized selling and increased volume of products from farm woodlots;

(2) Through these organizations to educate the owners toward a long term program of protection and management that will enable depleted woodlots to recover and productive ones to increase in capacity.

(c) Building up a utilization and marketing organization to provide an outlet for low grade products and to give producers bargaining power for higher grade material. This includes education on standards of measurement and quality and particularly aims at the improvement of quality and marketing practices for all products from fuelwood to high-grade hardwoods.

Considerable progress has been made in the co-operative production and marketing of pitprops and pulpwood. In 1940, pitprops to the value of $\$ 160$, 000 were handled through co-operative organizations and a central selling agency. It is planned to continue with these products and include lumber in the program. A more orderly marketing of sawn lumber will be attempted with the introduction of standard grades and greater co-operation of marketing agencies. Some progress has also been made in connection with Christmas trees. It is believed that this business can be developed and improved from the farmer's standpoint by co-operative production and marketing.

The danger in this program seems to be the development of production and marketing beyond corresponding development in forest management. This 
would lead in time to exploitation and the reduction of the productive capacity of the woodlots. Results of the program being undertaken should be watched with great interest by foresters and farmers in Canada.

\section{New Brunswick}

Farm woodlots in New Brunswick cover an area of 2,500,000 acres or about eighteen percent of the forest area of the province. In addition to this 1,650,000 acres are owned in lots of less than 500 acres. There also are numerous small Crown Land Timber Leases held by farmers so that the area of forest land owned or controlled in small lots is more than thirty per cent of the total. Records of production from these areas are not available but they contribute a considerable share of the raw material for an annual production valued at about forty million dollars.

Woodlots vary in size, but most of them are large enough to supply a surplus of fuelwood and some pulpwood or logs for sale. Many farmers own woodlots in addition to forested areas on the farms they occupy and operate several hundred acres of forest. Products are firewood, pulpwood, sawlogs, etc., varying according to the type of forest and the market. Market for firewood is limited by transportation costs to centres of population.

Education efforts in New Brunswick have been confined almost entirely to forest protection. These have had considerable success. A forestry extension service has been discussed for several years, but none of the organizations that might be interested have taken advantage of the opportunity. The problem in New Brunswick is one of providing information and advice regarding cutting and use and possible assistance in the organization of cutting and marketing. Like the other Maritime Provinces, reforestation and watershed, control are not now an important part of the problem.

Some progress has been made in New Brunswick in having information on elementary forestry included in the curriculum of the public schools. This seems to be a sound initial step and should lead to other developments. Quebec

The area of farm woodlots in the province of Quebec is about 9,000,000 acres. The annual cut from this area is nearly $200,000,000$ cubic feet of logs and lumber and about $2,000,000$ cords of firewood and other products.

The action of the Quebec Government through the Department of Lands and Forests to encourage and help the farmers in managing their woodlots may be summarized as follows:

1. Advisory service by Forest Engineers in connection with individual problems;

2. Distribution of bulletins on farm woodlot management;

3. Free planting stock for non-productive fields and windbreaks;

4. Organization of "Arbor Days";

5. Radio lectures dealing with the protection and management of farm woodlots;

6. Courses in elementary silviculture at intermediate schools of agriculture;

7. Creation of a Commission charged with making an inquiry into the prices paid for the pulpwood sold by farmers. 
To encourage planting and reforestation of non-productive lands the following legislation has been passed:

"Whosoever plants one thousand trees to the acre on land unfit for cultivation, belonging to him, may take advantage of the reward which the Lieutenant-Governor in Council may be pleased to fix, provided that the plantation has been kept in good order for at least five years."

"So long as at least three hundred trees to the acre are kept, lands replanted in trees shall retain, for a period of thirty years, the valuation which they had before the planting; at the expiration of such period of thirty years, the municipal valuation of such plantations, provided they remain as wooded land, can only be changed every ten years."

"All lands reforested and receiving a reward shall be subject to forest laws."

This program is well established and is much appreciated by the farmers. It will without doubt be expanded as need arises to meet new problems.

\section{Ontario}

Conditions in Ontario vary widely. There are problems of reforestation and watershed control as well as the ordinary problems of cutting and marketing found in other parts of Eastern Canada. The province has maintained an extension and reforestation service for many years. During 1941 the service has been decentralized. Previously all work was done from the head office in Toronto with five foresters working on reforestation and one on woodlots. Now the province has been divided into regions and reforestation and extension will be handled from regional offces.

Four hundred demonstration woodlots have been established. These are suitably located on some farm in a community. The farmer does the work with the advice of the extension forester. He allows signs to be placed and the woodlots used for demonstration purposes.

School woodlot meetings were held with the co-operation of the Departments of Education and Agriculture and county Conservation and Reforestation Committees.

Lectures on woodlot management were given at the one-month agricultural courses conducted by the Department of Agriculture.

Extension forestry is firmly established as an important Provincial Government service in Ontario and is in a position to deal with new problems which may arise in this Province.

\section{British Columbia}

\section{FOREST FIRES}

Summary

Daily measurements of forest-fire hazard by means of fire-hazard sticks continued to give valuable information which was used as a determining factor in relation to forest closure orders. Close co-operation was main.tained with the weather bureau in the exchange of weather information. 